\title{
Managing Fruit Orchards to Minimize Hurricane Damage
}

Jonathan Crane ${ }^{1}$, Carlos Balerdi ${ }^{2}$, Richard Campbell ${ }^{3}$, Carl Campbell', and Seymour Goldweber ${ }^{2}$

Additional index words. reset, storm damage, typhoon

Summary. Hurricanes occur periodically in southern Florida, resulting in severely damaged or destroyed orchards due to high winds, fresh-water flooding, and salt damage accompanying these storms. Commercial fruit production is often markedly reduced following hurricane damage. Orchard establishment and management practices that increase tree rooting depth and reduce tree size decrease tree losses due to high-velocity winds that accompany these storms. Cultural practices, such as post-hurricane pruning, whitewashing, resetting, and irrigation of trees, can rehabilitate a damaged orchard. Planning for a hurricane will increase the ability of orchards to withstand a storm and resume fruit production as soon as possible following a storm.

\section{Background}

Southern Florida has experienced numerous hurricanes (1926, 1928, $1929,1935,1945,1960,1964,1965,1966)$, the most recent of which occurred on 24 Aug. 1992 (Hurricane Andrew). Andrew was rated as a category 4 hurricane by the National Weather Service, with sustained winds of $145 \mathrm{mph}(233 \mathrm{kph})$ and gusts $>175 \mathrm{mph}(282 \mathrm{kph})$.

Estimated destruction from Hurricane Andrew was 35\% to $45 \%$ of the 22,000 acres (8903 ha) of commercial tropical fruit crops grown in Dade County, Fla. Prior to the storm, the commercial fruit industry was worth $\$ 75$ million annually in gross sales (Mosely, 1990). Commercial growers are presently assessing their options, such as replanting the same or a different crop; rehabilitating damaged trees, irrigation systems, and equipment; or abandonment.

Winds from Hurricane Andrew caused almost complete defoliation of all fruit crops, moderate to severe limb damage, trunk twisting and breakage, tree toppling, uprooting of entire trees, and the loss of

${ }^{1}$ Tropical Fruit Crops Specialist and Tropical Fruit Crops Specialist, Emeritus. University of Florida, IFAS, Tropical Research and Education Center, Homestead, FL 33031-3314.

${ }^{2}$ Multi-County Tropical Fruit Crops Extension Agent and Multi-County Tropical Fruit Crops Extension Agent, Emeritus. Dade, IFAS Cooperative Extension Service, Homestead, FL 33030.

${ }^{3}$ Curator of Tropical Fruit/Extension Horticulturist, Fairchild Tropical Garden, Miami, FL 33156-4296

Florida Agricultural Experiment Station Journal Series no. R-03660. The cost of publishing this paper was defrayed in part by the payment Of Page charges. Under Postal regulations, this paper therefore must be hereby marked advertisement solely to indicate this fact. 
Danning for
a hurvicane

enables growers to

make sound

decisions before

and after a storm

and increases the chances of rapid

recovery. almost all fruit (Fig. 1). In addition to the direct effect of the strong winds, wind-blown debris, such as loose sand and rock from adjacent open fields, stripped bark off of trees (sandblasting) (Fig. 2). In some cases, $50 \%$ or more of the bark on the trunk and major limbs was destroyed. Wind-blown trees also caused extensive damage to adjacent trees, fences, and equipment as they were swept by the hurricane-force winds. Damage to young trees was especially severe (Fig. 3). Differences in the response to the hurricane occurred among fruit species and cultivars of a single species (Campbell et al., 1993; Crane et al., 1993, 1994). This article focuses on pre- and post-hurricane cultural practices used in the tropical fruits industry of South Dade County, Fla., and their effects on plant recovery and survival.

\section{Pre-hurricane practices}

Planning. Planning for a hurricane enables growers to make sound decisions before and after a storm and increases the chances of rapid recovery. Southern Florida's hurricane season is from June through about midOctober each year. However, preparations for a hurricane should be made well before a hurricane watch or warning is announced. This is because cultural practices, such as pruning, topping, and hedging, prior to a hurricane take time, labor, and equipmentall in short supply just before a hurricane.

Components of a hurricane plan should include insurance coverage for equipment, buildings, and orchards (including crop loss); accumulation and safe storage of equipment needed in the recovery. such as saws, slings, shovels, fuel, paint, and equipment parts; and the knowledge of the location and cost of backhoes, front-end loaders, and wood chippers. Prioritizing which orchards will be worth
Fig. 1. Toppled, uprooted, defoliated, and defruited 'Booth-8' avocado (Persea americana Mill.) trees.

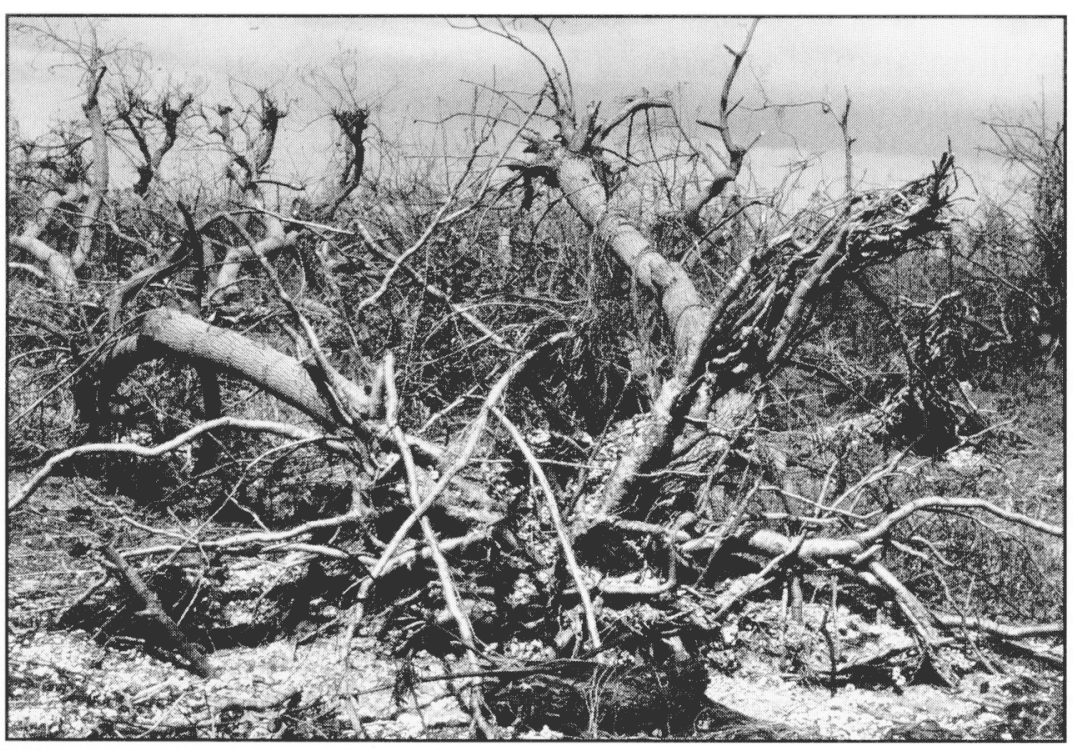

resetting, clearing and replanting with the same or a different crop, or top-working is equally important.

Site selection. Choice of a planting site is an important consideration that can affect the amount of hurricane damage. Natural woodlands can significantly reduce the velocity of winds during storms. They also reduce bark damage to fruit trees caused by windblown sand and gravel from open fields. Sites with planted windbreaks also afford some wind protection as long as the windbreak trees are well-rooted and have been topped, thus reducing the chances of their toppling into the adjacent fruit trees.

Preplant soil preparation. In Dade County, most tropical fruit crops are grown on a hard, but porous, Oolitic limestone soil, commonly called Rockland soil (Calhoun et al., 1974; South Dade Soil and Water Conservation District, 1989). During the 1930s, toothed, heavy steel drags were pulled across the cleared land to breakup the rock to a 4- to 6-inch $(10-$ to $15-\mathrm{cm})$ depth, and trees were planted in shallow holes of about a 12-to 16inch (30- to 40-cm) depth (flat-planted). During the 1940s, heavy tractors with 42-inch $(107-\mathrm{cm})$-wide front-end plows ("rock plows") were developed to scarify the limestone rock to a 4 - to 6 -inch (10- to $15-\mathrm{cm})$ depth. After rock-plowing, front-end trenching plows were used to make trenches [16 to 18 inches wide and 18 to 24 inches deep (41 to $46 \mathrm{~cm}$ wide and 46 to $61 \mathrm{~cm}$ deep)] in rows corresponding to tree rows and tree spacing distances (Colburn and Goldweber, 1961). Trees then were planted at the intersection of the crossed trenches, which greatly increased the depth and volume of soil available for rooting and anchoring trees.

Past hurricanes in southern Florida showed that preplant practices that increase the soil depth available for rooting increase tree stability during high winds. "Flat-planted" trees generally toppled during a hurricane, revealing a shallow, but extensive, lateral root system (Colburn and Goldweber, 1961). Trees planted in cross trenches have an extensive root system along the trenches, as well as surface roots, and thus often remain upright.

More recent observations after Hurricane Andrew suggest that some trees grown in cross-trenched orchards broke off along the trunk, leaving only a jagged stump (Fig. 4). Thus, while the tree was well-anchored, the trunk could not withstand the wind stress. There may be some argument for flat-planting trees that can be reset after toppling. However, in many cases, flat-planted trees were uprooted completely or blown away.

Grafted vs. air-layered trees. A number of fruit crops, such as 'Tahiti' lime (Citrus latifolia Tanaka), lychee (Litchi chinensis 
Sonn), longan [Nephelium longana (Lam.) Carm.], and guava (Psidium guajava L.) have been propagated by air layering (marcotting) for commercial plantings in southern Florida for many years. Air layering was practiced because grafting was difficult for some species, such as lychee and longan. Air layering was highly successful, relatively easy, and trees generally come into production about a year ahead of grafted trees.

Hurricanes during the 1960s revealed that grafted lime trees withstood the high winds, while air-layered trees were toppled or blown out of the ground. After Hurricane Andrew, a survey of mature lime orchards established with grafted, air-layered, or alternating grafted and air-layered (mixed orchard) trees found that $93 \%$ to $96 \%$ of the trees in the grafted orchards, and $89 \%$ of the trees in the mixed orchard, survived the storm, compared to $17 \%$ of the trees in the airlayered orchard (Crane et al., 1994). Observation suggests that the root systems of airlayered lime trees do not have the depth or lateral spread of grafted trees, at least under South Dade County soil conditions. In contrast to air-layered lime trees, a majority of the air-layered guava $(84 \%)$, longan $(70 \%)$, and lychee $(60 \%)$ trees surveyed survived the hurricane (Crane et al., 1994).

Tree size control practices. The canopies of trees, especially mature trees, resist wind movement, although there is much difference among species. If the wind is of sufficient speed and duration, trees may have leaves blown off, limbs broken, trunks snapped and/or twisted off (at or near the soil), or be toppled or blown out of the ground.

The most beneficial pre-hurricane cultural practice to reduce tree damage and toppling is a regular pruning program to control tree size (Fig. 5). Tree size may be reduced by topping and hedging with heavy equipment (Newman, 1971; Phillips, 1972) and/or with hand-operated saws and pneumatic shears for selective limb removal. Other benefits of tree size control include ease of harvest, increased penetration and efficiency of foliar sprays, increased light and air penetration, retention of a lower bearing canopy, and improved equipment movement through the orchard.

A post-Hurricane Andrew survey found the percentage of trees toppling over and surviving varied with fruit species, the age of the trees, and tree height prior to the storm (Crane et al., 1994). In general, we found that, in orchards where tree height was limited to 12 to $22 \mathrm{ft}$ ( 3.7 to $6.7 \mathrm{~m}$ ), more trees remained upright than in those orchards where no tree height control was practiced. In an orchard rejuvenation study with avocado (Crane et al., 1992), the fewest toppled trees after Hurricane Andrew were in treatments where trees were topped to $12 \mathrm{ft}(3.7$ $\mathrm{m})$ and every other tree was removed on the diagonal (unpublished data). In contrast, more nontopped trees [30 to $60 \mathrm{ft}(9$ to $18 \mathrm{~m})]$ and trees topped to $16 \mathrm{ft}$ and $22 \mathrm{ft}(4.9$ $\mathrm{m}$ and $6.7 \mathrm{~m}$ ), with or without every other tree removed, had fallen.

Windbreaks. The benefit of windbreaks depends on whether they withstand high winds, remain upright and mostly intact during a hurricane, or topple, uproot, and destroy the trees they were intended to protect.

In southern

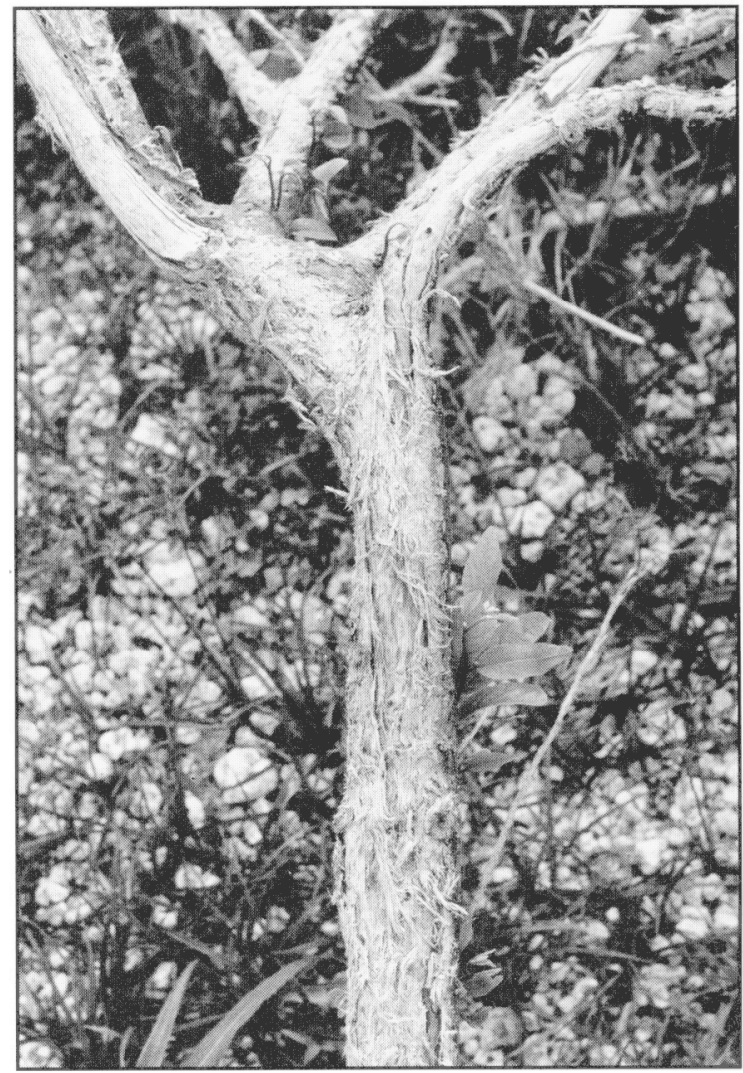

Florida, traditional flat-planted windbreaks of Australian pines (Casuarina equisetifolia J.R. Forst. \& G. Forst.) resulted in heavy damage to fruit trees after a hurricane when they fell into the orchards (Brooks, 1946; Loomis, 1946). In addition, they increased the orchard restoration cost because windbreak trees had to be removed. Observations from previous hurricanes showed that no common windbreak species withstood hurricane winds in excess of $100 \mathrm{mph}$ (161 kph) without serious damage or uprooting (Ruehle, 1963). Similar problems with planted windbreaks were observed after Hurricane Andrew.

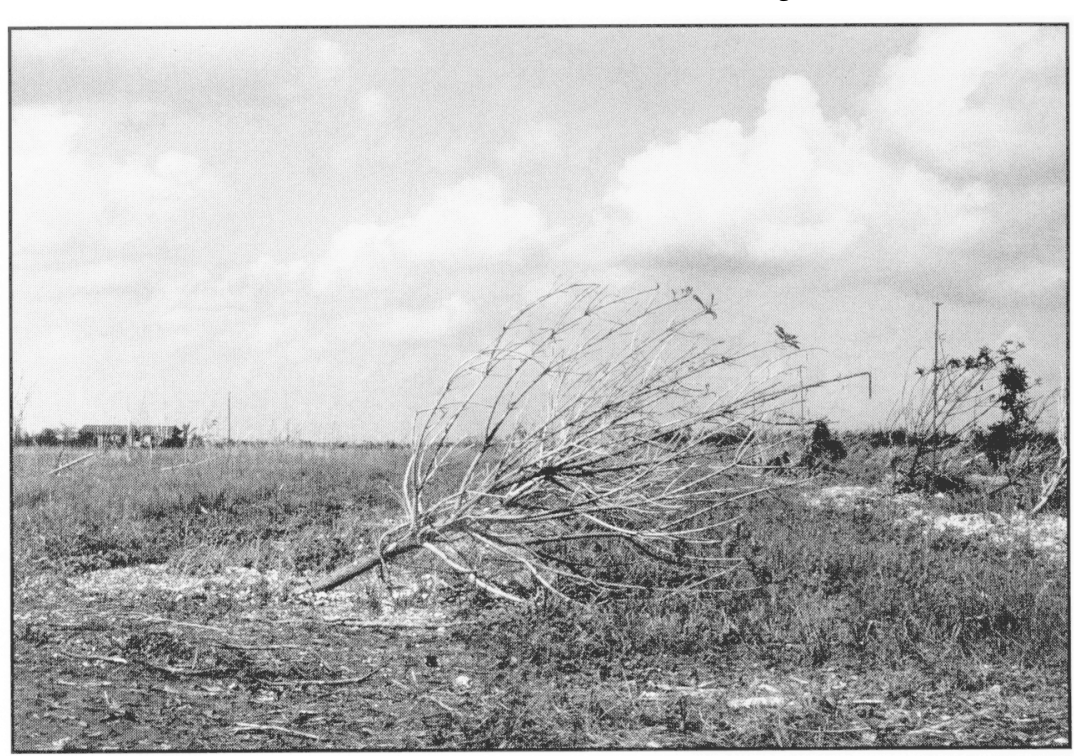

Fig. 2. 'Gefner' atemoya (Annona squamosa x A. cherimola) limb showing extensive bark damage due to wind-blown soil and rocks. canistel (Pouteria campechiana Baehni) orchard depicting missing trees, toppled, defoliated, defruited. and barkdamaged trees.
Fig. 3. Three-year-old 


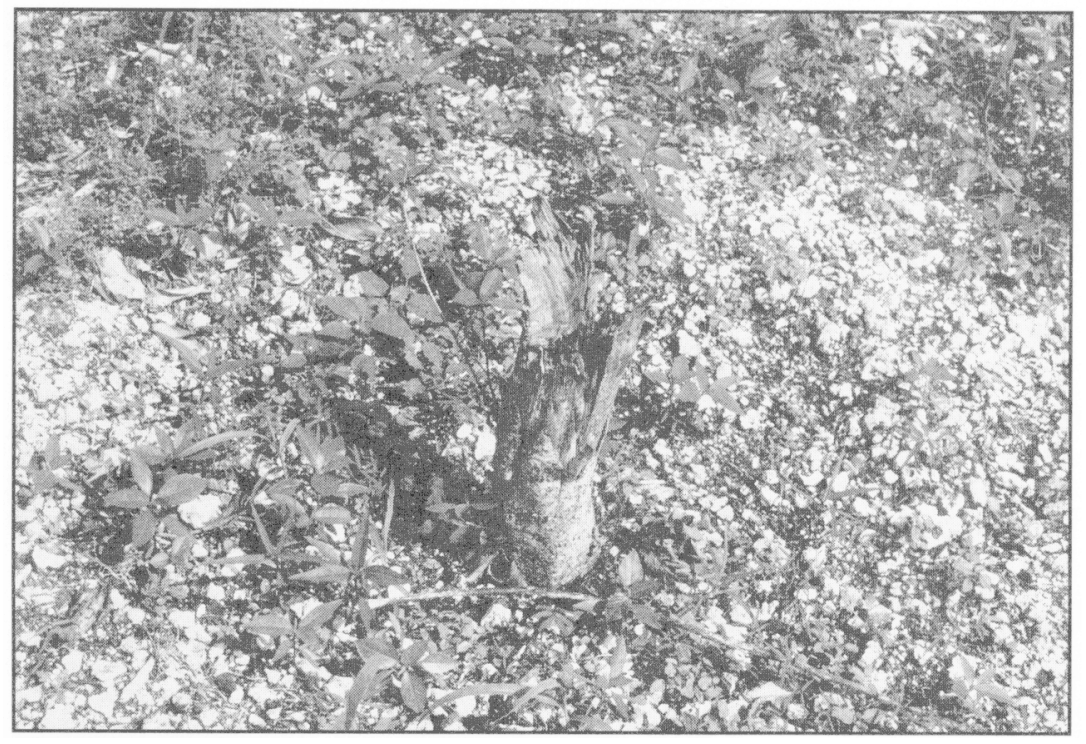

Fig. 4. Stump of 'Gefner' atemoya tree in trenched orchard.

Fig. 5. An avocado orchard topped at about $3.7 \mathrm{~m}$ prior to Hurricane Andrew in which most trees remained standing
Human-constructed windbreaks have become common for carambola production in southern Florida. These windbreaks may be up to $22 \mathrm{ft}(6.7 \mathrm{~m})$ high and may surround an entire planting or just the orchard perimeters not protected by natural windbreaks. Typically, they consist of aluminum or wooden pole support structures from which shade cloth is attached vertically by cables. In most instances, the orchards also are sectioned-off inside the orchard with vertical shade cloth suspended 12 to $20 \mathrm{ft}$ (3.6 to $6.1 \mathrm{~m}$ ) above the orchard. These windbreaks work well to reduce windy conditions [5 to $36 \mathrm{mph}$ ( 2 to $16 \mathrm{~m} \cdot \mathrm{s}^{-1}$ or more)] commonly experienced from November to March (Crane and Schaffer, 1992), thus allowing trees to grow vigorously and produce fruit (Crane, 1992). However, the windbreaks used at present did not survive the 233 -kph winds of Hurricane Andrew intact (Fig. 6). All of the windbreaks lost their shade-cloth screen and some lost their support structures.

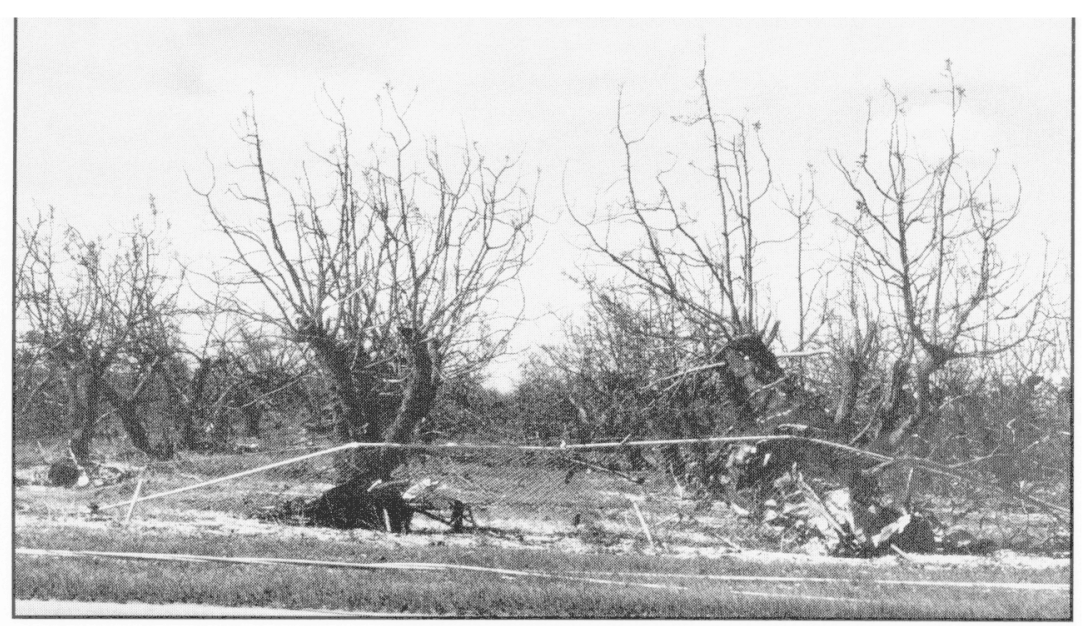

On the other hand, orchards adjacent to woodlands and planted windbreaks that had been topped had fewer toppled fruit trees and much less damage from windborne loose rock and sand than trees in unprotected orchards.

Miscellaneous practices. Removing risers from overhead irrigation systems before a hurricane will dramatically reduce the amount of damage to risers and the underground piping of the system. Placing pumps and engines in an enclosed building also will reduce the chances of their damage. However, moving such heavy equipment may not be practical.

\section{Post-hurricane practices}

The first step after the hurricane is to make a visual assessment of the damage to estimate the cost of resetting the orchard. Once the equipment and labor has been assembled, debris removal, pruning of damaged trees, and resetting of toppled trees can begin.

Resetting trees should be accomplished as soon as possible after a hurricane. The timing, however, may depend on many factors, including the cost and availability of equipment and labor. The amount of root damage, the amount of the root system remaining in the ground, and the amount of soil left around the exposed roots should determine which trees to reset first. If possible, mounding soil on exposed roots or providing some type of shade will help keep the tree roots alive until resetting is possible.

Equipment. The equipment needed for resetting trees after a hurricane include handpruning saws, chain saws, combination frontend loaders and backhoes, picks, shredders or chippers, shovels, hand hoes and loppers, and slings or large-diameter ropes for resetting fallen trees. Slings should not be made of cable or chain because they may damage the bark and cambial layer and may girdle already damaged and stressed trees. Cables have the added danger of being extremely dangerous to workers if they snap.

Protecting sun-exposd trunks and limbs. Cambial damage ("sunburn") may occur to defoliated and/or toppled trees exposed to direct sunlight for prolonged periods (Boyce, 1961; Levitt, 1980; Tattar, 1978). This injury is thought to be caused by overheating of the cambium layer, and symptoms include drying and peeling of the bark, defoliation, branch dieback, wood injury, and growth of saprophytic fungi on dead bark and wood.

Spraying or painting tree trunks and branches with white water-based latex paint before or immediately after a hurricane will help prevent cambial overheating due to sun exposure. The latex can be diluted with water in a 1:1 ratio (whitewash). If latex is not 
available, a whitewash can be made by mixing water, fine-grade hydrated lime, and zinc sulfate in a 1:1:0.1 ratio. The zinc sulfate should be dissolved in water first. The mixture can be diluted to the desired consistency with water for application purposes. If the material is to be applied with a mechanical sprayer, it will have to be strained first and diluted further.

Prunning. Pruning maybe a part of the debris removal and preparation for resetting toppled trees. Pruning cuts should be made back to sound wood, as in normal selective pruning practices. This includes pruning back to lateral buds, to the nearest crotch, or to the trunk. Additional pruning will be essential for proper tree management as new growth continues to develop and trees recover. In some cases, this may be a good time to cut trees back for topworking to more desirable cultivars.

Toppled trees also should be pruned back to sound wood. However, because of the extensive root damage of partially uprooted trees, a moderate to large amount of the tree canopy may have to be removed. Removing part or most of the canopy reduces the weight of the tree, making resetting and stabilizing the tree easier, and will also reduce the transpirational surface area. Depending on the size of the tree and amount of damage, it may have to be cut back to main scaffoldlimbs or to the trunk (stump). Some trees may shift back to their original position as the tops are removed. This can be dangerous for anyone pruning the tree or working near the root mass or trunk.

During the pruning process, braces may be made by cutting 4 - to $10-\mathrm{ft}$ (1.2- to 3.1 m) -long limbs of 4 to 6 inches ( 10 to $15 \mathrm{~cm}$ ) in diameter with forked branches. These braces can be used to help stabilize trees after the resetting process.

Pruned-off branches can be stacked in the row for natural decomposition, removed from the orchard, chipped or shredded at the orchard; or burned. Burning is not recommended because of air pollution, whereas chipped wood can be used immediately as mulch or composted for later use. Non-plant debris, such as metals, plastics, and rubber, should be removed and stacked outside the orchard for later removal.

In some instances, when it is impossible to reset the trees immediately, pruning to remove most of the canopy of toppled trees will reduce their transpiration loss and prevent desiccation. In addition, the pruned-off branches can be draped over the remaining trunk and scaffold branches for protection against sunburning. However, this may afford protection for wood-boring insects from natural enemies (S. Goldweber, personal communication).

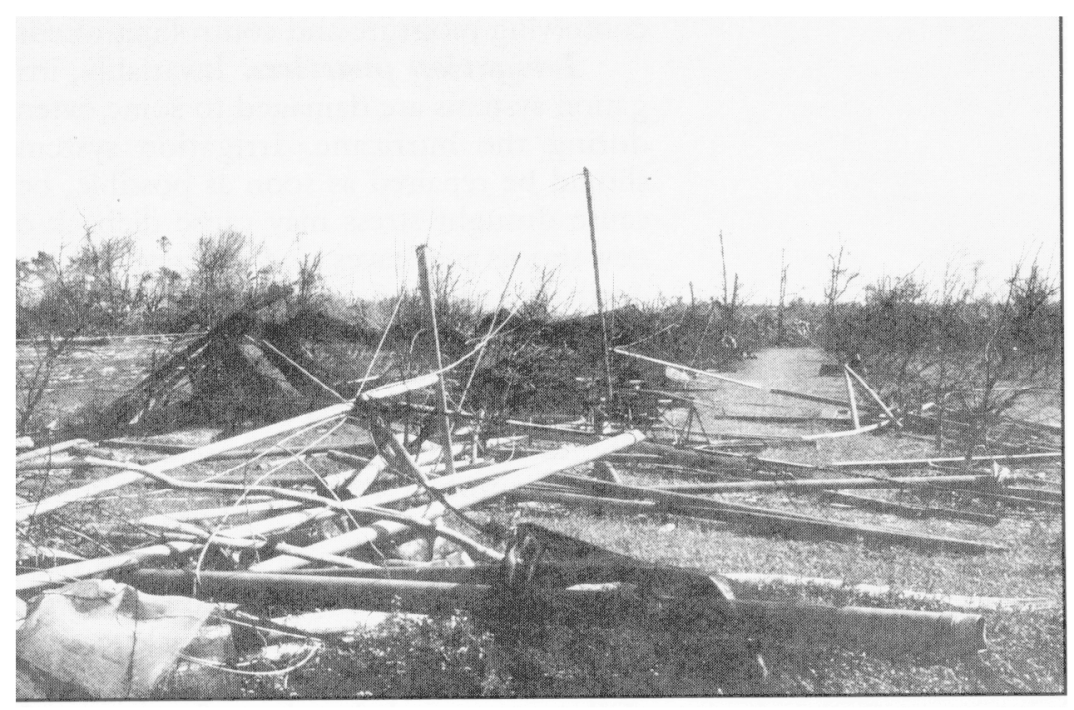

Once plant and non-plant debris have been removed and the orchard or some part of the orchard has been cleared, redigging planting holes and resetting fallen trees can begin.

The resetting operation. Before resetting a tree, lateral and vertical roots completely out of the ground and damaged roots should be removed with a lopper and/or a saw. This will enable the tree to stand level when reset. A backhoe or similar machine should remove enough soil from the tree hole so that the tree will stand at or near the same level as before. Soil underneath the root mass of the fallen trees also may be removed by hoes and shovels.

Heavy-duty slings or ropes attached to tractors or backhoes can be used to assist in raising the trees to an upright position. Precut braces can be used to stabilize or prop the trees after they are raised (Fig. 7). The hole should be filled with excavated soil and the soil "flooded-in." The use of wood chips or

Fig. 7. Guava (Psidium gaujava L.) trees reset and popped witb guava limbs cut from tippled trees.

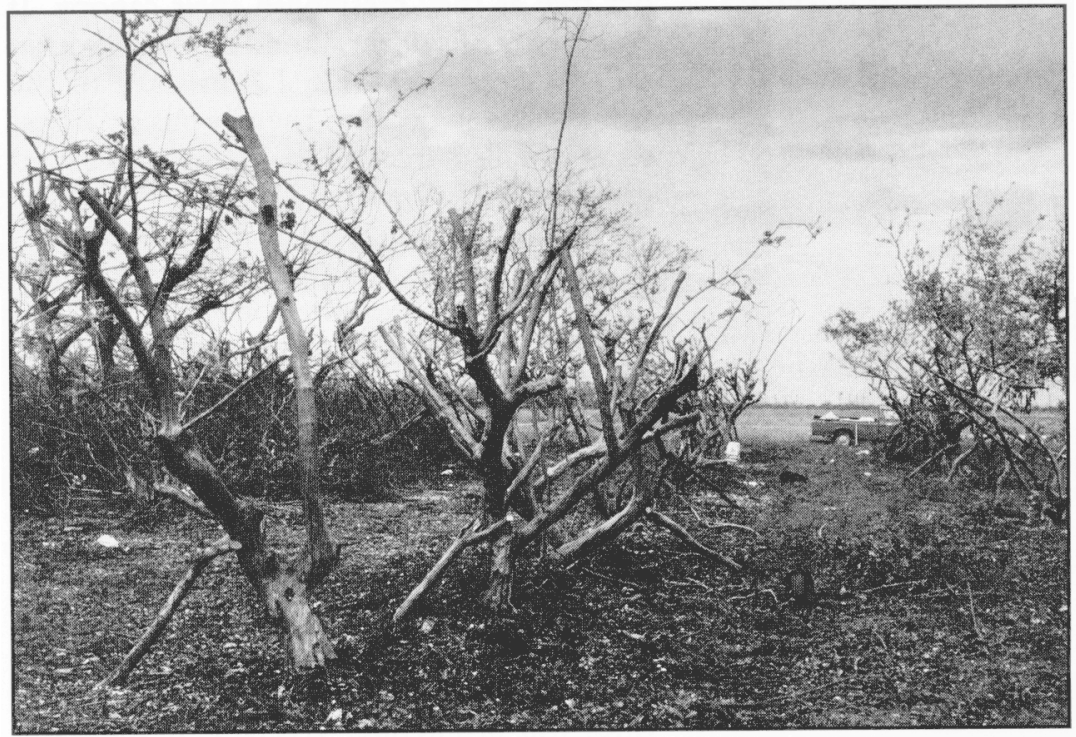


The three most-important pre-hurricane practices are the use of grafted plant material, preparation of planting sites to increase rooting depth available for anchoring trees in place, and maintenance of a regular pruning program to limit tree size. other mulch on top of the soil is helpful in conserving moisture and controlling weeds.

Irrigation practices. Invariably, irrigation systems are damaged to some extent during the hurricane. Irrigation systems should be repaired as soon as possible, because drought stress may cause dieback of new shoots and leaves, and may result in tree death. In addition, high-volume sprinklerirrigation systems need to be working for cold protection of cold-sensitive trees. We recommend irrigating at least twice per week at a 0.5 - to 1 -inch $(1.3-$ to $2.5-\mathrm{cm})$ rate per irrigation until trees become reestablished well.

Salt damage to trees depends on plant tolerance, whether the roots are immersed (salt water intrusion), whether salt water is deposited by wind (foliar), salt concentration of the water, and duration of exposure. If irrigation is available after a storm, irrigation to wash salt off remaining foliage and to leach salts in the soil beyond the root zone will help reduce salt damage to sensitive trees.

Fertilizer practices. Obtaining fertilizers and distributing them to reset or reconditioned trees may not be possible and/or may be of secondary importance immediately after a hurricane. However, major fertilizer elements should be applied when new growth begins to preclude nutrient deficiencies after stored reserves in the trees are depleted. Fertilizer rates for trees with limb loss should be reduced in proportion to the amount of tree damage, keeping in mind that previously fallen trees will have a damaged and muchreduced fibrous root system. More-frequent light applications of low-analysis fertilizers may ensure a steady supply of nutrients and aid in a rapid recovery of canopy, limbs, and roots. In contrast, trees that lost mainly only leaves and remained upright should receive slightly greater-than-normal rates of fertilizer per tree as they reestablish their canopy. If possible, the fertilizer should be placed within a 3- to 6-foot (0.9- to $1.8-\mathrm{m})$ area of the trunk. This is because the fibrous root systems of fallen trees probably have been reduced and damaged.

Micronutrients such as $\mathrm{Mn}$ and $\mathrm{Zn}$ commonly are applied to foliage in South Dade County because the limestone-based soil has a $\mathrm{PH}$ of 7.5 to 8.5 . As trees refoliate, micronutrients such as $\mathrm{Mn}$ and $\mathrm{Zn}$ should be applied to the leaves. Chelated iron soil drenches also should be applied as the trees begin defoliation.

Weed control practices. Weed control may be difficult after a storm due to a lack of equipment, materials, or labor. However, because more of the land surface area is exposed to direct sunlight, weeds and weedy vines will proliferate. Weeds and vines will compete with the trees for sunlight, water, and nutrients and become more difficult to control as they mature. When row middles become accessible, mowing and herbicide applications should be resumed.

Mulching practices. The use of a mulch (wood chips) around the trees will be helpful in conserving soil moisture and reducing weed growth. Mulch should not be mounded against the trunks, as continuous moisture along the trunk may facilitate attack by fungi and borers. The mulch should be kept at least 6 to 12 inches ( 15 to $30 \mathrm{~cm}$ ) from the trunk.

Some fruit tree species (e.g., lychee, mango, and avocado) may be injured by thick layers of mulch and/or certain mulch materials. If in doubt, only weathered materials that are coarsely textured should be used and applied in thin layers of no more than 2 to 4 inches $(5$ to $10 \mathrm{~cm}$ ). Slightly increased fertilizer rates, especially of $\mathrm{N}$, may be necessary because some of the fertilizer will be used by microorganisms decomposing the compost (Brady, 1974).

Insect and disease control practices. Depending on location, various primary and secondary pathogens may attack defoliated and weakened trees. In addition, insect pests may attack what are usually considered nonhost species. This may be due to a lack of normal host plant material or to decreased resistance of stressed plants. Local extension personnel should be contacted for identification and control recommendations.

\section{Conclusion}

Planning for a hurricane will help reduce damage to fruit trees and enhance recovery of the farming operation. The three most-important pre-hurricane practices are the use of grafted plant material, preparation of planting sites to increase rooting depth available for anchoring trees in place, and maintenance of a regular pruning program to limit tree size. After a hurricane, being prepared for clearing debris, resetting toppled trees, protecting trees from sunburn, irrigating, and fertilizing trees frequently will increase chances that the trees will recover and the farming operation will survive.

\section{Literature Cited}

Boyce, J.S. 1961. Forest pathology. McGraw-Hill, New York. p. 38-39.

Brady, N.C. 1974. The nature and properties of soils, 8th ed. Macmillan, New York. p. 150-163, 546-550.

Brooks, J.R. 1946. Hurricane damage to commercial fruit trees in Dade County. Proc. Fla. State Hort. Soc. 59:149-151. 
Calhoun, F. G., V.W. Carlisle, R.E. Caldwell, L. W. Zelazny, L.C. Hammond, and H.L Breland. 1974. Characterization data for selected Florida soils. Univ. of Florida, IFAS Soil Sci. Dept., Soil Characterization Lab. and USDA Soil Conservation Serv. Jan. 1974.

Campbell, R.J., C.W. Campbell, J. Crane, C. Balerdi, and S. Goldweber. 1993. Hurricane An drew damages tropical fruit crops in south Florida. Fruit Var. J. 47:218-225.

Colburn, B. and S. Goldweber. 1961. Preparation of oolitic limestone soil for agricultural use. Proc. Fla. State Hort. Soc. 74:343-344.

Crane, J.H. 1992. The carambola. Fla. Coop. Extn. Serv., IFAS, Univ. of Florida, Gainesville. Fact Sheet FC-12.

Crane, J.H., R.J. Campbell, and C.F. Balerdi. 1993. Effect of hurricane Andrew on tropical fruit trees. Proc. Fla. State Hort. Soc. 106.

Crane, J.H. and B. Schaffer. 1992. Effect of wind speed on carbon assimilation, water relations, and growth of young carambola and sugar apple trees. HortScience 27:579. (Abstr.)

Crane, J. H., B. Schaffer, T.L. Davenport, and C. Balerdi. 1992. Rejuvenation of a mature, nonproductive 'Lula' and 'Booth 8 ' avocado orchard by topping and tree removal. Proc. Fla. State Hort. Soc. 105:282-285.
Crane, J.H., C. Balerdi, R. Campbell, C. Campbell, and S. Goldweber. 1993. Hurricane Andrew and south Florida's tropical fruit crops industry. The Fla. Grower and Rancher 86:25-27.

Levitt, J. 1980. Responses of plants to environmental stresses: Vol. 1, chilling, freezing, and high temperature stresses. Academic, New York. p. 347-391.

Loomis, H.F. 1946. Hurricane damage to tropical plants. Proc. Fla. State Hort. Soc. 59:146-149.

Moseley, A.E. 1990. Economic impact of agriculture and agribusiness in Dade County, Florida. Industry Rpt 90-4, Food and Resource Economics Dept., Univ. of Florida, Gainesville.

Newman, P. W. 1971. Current hedging and topping practices for avocados and limes in Florida. Proc. Fla. State Hort. Soc. 84:281-282.

Pbillips, R.L. 1972. Hedging angles for 'Hamlin' oranges. Proc. Fla. State Hort. Soc. 88:445-448.

Rueble, G.D. 1963. The Florida avocado industry. Univ. of Florida Cooperative Extension Serv. Bul. 602 .

Tattar, T.A. 1978. Diseases of shade trees. Academic, New York. p. 209-2 12.

South Dade County Water Conservation District. 1989. South Dade Soil and Water Conservation District Rpt. Tentative soil legend, Dade County, Fla., Homestead. 